\title{
SKRIFGESAG EN PREDIKING
}

\section{J A VOS}

\begin{abstract}
Scriptural authority and preaching

The point of departure for this article is that the Word of God has authority. Although there is formal concensus of opinion about this basic premise among the different schools of thought, there are important and even fundamental and unique differences of interpretation among them.

The diverse claims of the proponents of these viewpoints are addressed in this paper. The models dealt with are those of the fundamentalism, the relationalist approach, personal testimonies of faith, but above all, that of the Bible as the Word of God rendered in the language of men.

The Bible has been handed down to us as the indisputable gospel of Almighty God. Hence it should be studied with diligence, expounded and preached as such. If this is done, the innate authority of the preaching of the gospel as the Word of God, and the vital power of true gospel preaching will once more be given primacy in the church of God.
\end{abstract}

\author{
Voonwaar: \\ hier uit die klankoond \\ rys 'n brood \\ wat van Hom self suurdesem is. \\ Ernst van Heerden
}

\section{Die Woord van God het gesag}

\subsection{Die Skrifgesag - 'n sentrale kerklike en teologiese probleem}

Sonder vrees vir enige teëspraak kan gesê word dat die Bybel sentraal in die kerklike en teologiese besinning staan. Die Woord is die "siel van die kerk" (Calvyn) en alle diens in die kerk is diens van die Woord. ${ }^{1}$ Daar word in al die teologiese modelle in mindere of meerdere mate op die Bybel gesteun. Die beroep wat daar in die kerk en in die teologie op die Bybel gemaak word, is ' $n$ voortgaande proses. Kerklike uitsprake ontkom nooit hulle toetsingseis nie, en teologiese teorieë, verklaar Van Huyssteen ${ }^{2}$ met reg, is nie dogmatiese, afgeslote standpunte nie, maar voorlopige, tastende ontwerpe. Daarom moet kerklike uitsprake en teo- 
logiese teorieë steeds in die lig van die Bybelse uitsprake getoets word.

Die sentrale plek van die Bybel word deur die reformatoriese sola scriptura-uitspraak bevestig. Die sola scriptura-beginsel ken die alleenreg aan die Bybel toe as die primêre outoriteit vir die Christelike geloof en die Christelike teologie as die reflektiewe verstaan van die geloof. ${ }^{3}$ Die handhawing van dié beginsel word egter deur sommige teoloë ernstig bevraagteken. Die volgende redes word hiervoor aangevoer:

1.2.1 Die groeiende dialoog tussen die Protestantse en Rooms-Katolieke teologie;

1.2.2 Die ontwikkelinge op die gebied van die histories-kritiese verstaan van die Bybel;

1.2.3 'n Skerp reaksie in die Protestantse teologie teen alle vorme van fundamentalisme;

1.2.4 Die komplekse en uitdagende ontwikkelings van literêre benaderinge (vgl. in die verband die narratiewe eksegese; die struktuur- of strukturele analises; die semiotiek (die sintaksis, die semantiek en die pragmatiek)1.4

Hierteenoor moet gestel word dat die sola scriptura-beginsel onverswak gehandhaaf moet word en wel om die volgende redes:

1.2.1.1 Die Bybel is as die klassieke oorsprongsdokument van die Christendom ons enigste toegang tot God se gedagtes oor, woorde vir en dade met die mens en die wêreld. Dit is ook ons enigste toegang tot Jesus van Nasaret in Wie God Hom vir die Christen finaal geopenbaar het. ${ }^{5}$ Die belydenis van die sola scriptura het geen ander oogmerk as om die weg na solus Christus te open nie en die weg na Hom is die weg van die sola fide.

1.2.1.2 Alle ander religieuse tekste is ' $n$ interpretasie van die gesaghebbende oorsprongsdokument van die Christendom.

1.2.1.3 Die sola scriptura-beginsel bevestig ook die kanoniese belydenis aangaande die Bybel. Die feit dat Jesus van Nasaret na ' $n$ wêreld gekom het waar daar alreeds ' $n$ gesaghebbende versameling van godsdienstige tekste bestaan het asook 'n geloofsgemeenskap waarbinne dit aanvaar en geinterpreteer was, was inderdaad van groot betekenis. Die Ou Testament het die "godsdienstige paradigma" vir die Nuwe Testament 
gebied. Die tekste van die Ou Testament het die mees fundamentele konsepte, simbole en metafore vir die Jesus-kerugma van die vroeë kerk voorsien. ${ }^{6}$ Die kerk kon as geloofsgemeenskap in die lig van sy omgang met die tekste van die Ou en Nuwe Testament nie anders as om die gesagsposisie van die tekste te erken nie.?

\subsection{Die Skrifgesag in die lig van die Bybel se ontstaan}

Die Bybel het nie op 'n goeie dag persklaar uit die hemel geval nie. Aan die finale produk gaan 'n eeuelange groeiproses vooraf. Die vraag na die ontstaan van die Bybel moet dus vanselfsprekend aan die bod kom. Die ontstaansvraag word deur verskillende paradigmas beantwoord. In die artikel word daar aan die volgende paradigmas aandag gegee:

\subsubsection{Die fundamentalisme}

Die fundamentalisme verteenwoordig 'n reaksie op die 19de-eeuse Liberale Teologie wat sy ontstaan in ' $n$ aantal "Biblical conferences of conservative Protestants" gehad het. Die Niagara-konferensie van 1895 het ' $n$ verklaring uitgereik waarin die sogenaamde "vyf punte van fundamentalisme" opgesom is. Daarvolgens is die volgende geloofstukke onaanvegbaar en behoort dit tot die wese van die Christelike teologie: die letterlike feilloosheid van die Bybel; die Godheid van Christus; die maagdelike geboorte van Christus; die plaasvervangende sterwe van Christus; die liggaamlike opstanding en wederkoms van Christus. In wese berus die fundamentalisme op een punt, naamlik dat die Bybel letterlik deur God ingegee is - dus op ' $n$ meganiese inspirasieleer. ${ }^{8}$ Die leerstellings wat volgens ' $n$ fundamentalistiese patroon gevorm is, word as gesaghebbende en betroubare beskrywings van die Bybelse grondlyne aangebied. ${ }^{9}$ Die beskrywings word letterlik as 'n direkte "replika" van dit waarna dit verwys, verstaan. ${ }^{10}$ In hierdie paradigma word daar uit eerbied vir die gesag van die teks niks meer gesê as wat die teks self sê nie, al word die sin van wat die teks sê, nie ten volle verstaan nie. "Wat die etiese vrae betref, ywer die fundamentalisme daarvoor om ' $n$ geheel van onhistoriese, objektiewe en altyd geldende waarhede - of tydlose beginsels - in die Bybel aan te toon. ${ }^{12}$ Die gevolg van hierdie wyse van Bybelomgang is ' $n$ naïewe biblisisme waarin daar probleemloos en konteksloos op geisoleerde Bybeltekste teruggeval word. ${ }^{13}$

\subsubsection{Die relasionele benadering}

Die relasionele benadering word veral verteenwoordig deur die sinodale 
Rapport wat in 1980 deur die Sinode van Delft behandel en as waardevol en konfessioneel verantwoord bestempel is. Deputate is opgedra om dit te verwerk vir gebruik in gemeentes. Hierdie verwerking is aan die einde van 1980 gepubliseer onder die titel: God met ons ... over de aard van het Schriftgezag $\ldots^{14}$

Die hele rapport staan in die teken van die hermeneutiek. Dit konsentreer meer op die wyse waarop die Bybel verstaan moet word as op die vraag wat aangaande die ontstaan van die Bybel geglo moet word. Die hoofdoel is dus eintlik om te vra hoe die gesag van die Bybel in die praktyk van die geloof funksioneer.

Dit is ' $n$ grondoortuiging van die opstellers van die rapport dat die Bybel as Heilige Skrif gesien moet word, dat die Heilige Gees deur hierdie Skrif tot ons wil spreek en dat die rapport wil bydra tot 'n dieper verstaan van die Bybel as die Woord van God. ${ }^{15}$

Die rapport konfronteer ons egter ook dadelik met die grondprobleem van elke denkende Christen: die feit naamlik dat die Bybel deur verskillende mense op verskillende wyses gelees word, dat 'n "Bybelse standpunt" of "Bybelse waarheid" deur verskillende mense so verskillend geïnterpreteer kan word. ${ }^{16}$

Die verwarrende feit dat mense die Bybel verskillend lees, hang natuurlik saam met die feit dat mense onder "waarheid" beslis nie almal dieselfde verstaan nie. Die moeilike vraag: wat is volgens die Bybel "die waarheid"?, word in die geskiedenis van die Skrifgesagprobleem gewoonlik volgens twee uiterste standpunte beantwoord:

1.3.2.1 Die mees gangbare en populêre standpunt oor wat Bybels gesproke "waar" is, is dié waarin benadruk word dat iets waar is wanneer dit objektief vasstelbaar is, wanneer dit byvoorbeeld klop met 'n feitelike toedrag van sake. Toegepas op die denke oor die Bybel sou dit beteken dat alles wat geskryf staan presies so gebeur het as wat dit letterlik daar staan.

1.3.2.2 Teenoor hierdie "objektiewe" opvatting van wat Bybels gesproke waar is, is daar ook die "subjektiewe" waarheidsopvatting. Hiervolgens word die waarheid van die Bybel gemeet aan die mens se wysgerige of wetenskaplike insig. Die groot gevaar wat hier dreig is dié van subjektivisme: die gelowige mens word self die enigste maatstaf van wat as Bybels gesien sou kon word. ${ }^{17}$

Ten einde aan die gevare van sowel die objektivisme as die subjektivisme te ontkom, kies die rapport vir 'n relasionele waarheidsbegrip. Hieronder word verstaan dat die waarheid nie iets louter objektief is wat los van alle menslike kennis daarvan bestaan nie, maar dat dit ook nie net 
louter subjektief is in die sin dat die mens self kan uitmaak wat waar is nie. Die waarheid soos ons as mense dit ken, is altyd die produk van die subjek en die objek gesamentlik. Die waarheid het altyd 'n objektiewe en subjektiewe kant wat gelyktydig en onafskeidbaar in ons kennis van die waarheid teenwoordig is. lets is altyd waar "vir my", maar die resultaat van my insig is iets "objektief" wat van buite myself onder my aandag gekom het. ${ }^{18}$

Die waarheidselement wat in hierdie visie op die waarheid aanwesig is, kan nie ontken word nie. Dit gaan in die Skrif inderdaad om ' $n$ geloofswaarheid wat alleen reg geken kan word in 'n persoonlike verhouding tot Christus (vgl. 1 Kor 2:14-16). Die Skrifwaarheid is nooit 'n blote objektiewe kennis van feite nie, maar word alleen reg geken as die mens verstaan wat dit vir hom beteken. In dié sin is daar inderdaad ' $n$ betrokkenheid van die geloof op die openbaring.

Maar dit mag tog nooit beteken dat die mens se geloof die waarheid tot waarheid maak nie. Die betrokkenheid van die geloof op die openbaring mag nie verstaan word as twee gewigte wat in 'n weegskaal gebalanseer word nie. Waar dit gebeur, ontvang die openbaringswaarheid sy gewig van die menslike geloof. Meer nog: die openbaringswaarheid word dan afhanklik gestel van en bepaal deur die menslike geloof. Die waarheid van die Skrif word nie eers waar en normatief binne die relasionele ken van die waarheid nie. Die waarheid en die normatiwiteit van die Skrif lê nie in die menslike geloofsantwoord nie, maar in die gesagvolle spreke van God.

Die relasionele karakter van die verstaan van die waarheid word ook van toepassing gemaak op die ontstaan van die Skrif. Wat ons vandag op skrif het as Woord van God, is wat mense met God ervaar het en dit dan òf self neergeskryf het, òf oorvertel het sodat iemand anders dit later kon neerskryf - dus relasioneel waargeneem, ervaar en oorgedra. Hiervolgens is dit begryplik dat die Skrif nie soseer as God se getuienis deur en aan mense gesien word nie, maar veeleer as mense se getuienis van God se woorde en dade. Die inspirasie van die Skrif deur die Heilige Gees word nou 'n hele geskiedenis waarin die waarheid tot openbaring gekom het. Dit is ' $n$ geskiedenis wat bestaan uit gebeurtenisse van lank gelede, woorde van aartsvaders en profete, oorleweringe, ' $n$ veelheid van bronne, die opteken van feite, die vasstel van wat wel en wat nie tot die kanonieke boeke van die Bybel behoort nie, die werk van Skrifgeleerdes, redakteurs, teoloë en gemeentegroepe. Dit alles word nog steeds voortgesit deur die hersiening en hernuwing van belydenisse en eksegese van die Christelike gemeente tot vandag toe. ${ }^{19}$ Binne die raam van die relasionele waarheidsbegrip word die inspirasie deur die Heilige Gees, anders as in die gereformeerde teologie, nie beperk tot die ontstaan van 
die Skrif nie, maar uitgebrei tot die proses van omgang met die Skrif in kerk en teologie. ${ }^{20}$ Die gevolg van hierdie opvatting van die inspirasie van die Skrif lei daartoe dat uitsprake in kerk en teologie normerende in plaas van genormeerde gesag kry.

Hoewel dit die uitgesproke oogmerk van die relasionele waarheidsopvatting is om die gesag van die Skrif te eerbiedig, ontkom dit nie die gevaar van 'n relativering van die Skrifgesag nie.

\subsubsection{Getuienisse van geloofsoortuigings en geloofsuitings}

Ferdinand Deist beoog om die verwikkelde vraagstuk van die Skrifbeskouing vir die gelowige nie-teoloog toeganklik te maak. Deist slaag voortreflik daarin om heerlike en voedsame spyse op te dis. Die nie-teoloog het immers ook kos nodig om van te lewe. En as dit boonop smaaklik is, is dit ' $n$ feesmaal. En tog lewer Deist se resep ook disse op wat teologieskrities beproef (beoordeel) moet word. Die rede hiervoor is dat hy sy spyse miskien soms met te veel speserye en sout bedien. Dit is veral Deist se siening van die aard van die Bybel wat sekere vrae oproep. Maar laat Deist eers self aan die woord gestel word:

“Die Bybel is 'n getuienisboek waarin die geloofsoortuigings en geloofsuitinge van meer as duisend jaar opgeteken is, duisend jaar waarin alles nie maar konstant en stabiel gebly het nie, maar waarin sienings van en oor God verander het, waarin mense nader aan die Lig beweeg het." 21

"Die produk van hulle gelowige denke en dade staan vir ons opgeteken in die Bybel, wat wonderbaarlik deur die millennia heen vir ons bewaar gebly het."22

"Wat ons daar het [nl. in die Bybel - CJAV], is brokstukke van getuienisse ... Ons het dus hier te make met 'n baie fragmentariese bundel getuienis van mense wat in húlle omstandighede gesoek het na die waarheid omtrent hulle lewe en omtrent God." 23

Niemand sal met Deist wil stry oor sy opvatting dat die Bybel 'n getuienisboek is nie. Die Bybel is egter nie net 'n getuienisboek van geloofsoortuigings en geloofsuitings nie. Ons sal meer as dit moet sê. Daarom moet ons bely dat die Bybel as getuienisboek óók ' $n$ openbaringsboek is. Dit beteken dat die Bybel nie soos Deist reken, ' $n$ produk van mense se gelowige denke en dade is nie, maar dit is die produk van God se wysheid en dade. In dié produksieproses het God beslag gelê op mense sodat die woorde en handelinge van God en die menslike ervaring daarvan 'n skriftelike neerslag gekry het. Deist sê ook te min as hy beweer dat dit in die Bybel om mense se soeke na die waarheid omtrent hulle lewe en omtrent God in hulle omstandighede gegaan het. Die Bybel 
is óok 'n getuienis dat God Hom aan mense openbaar: dat Hy mense opsoek en vind en dat mense om dié rede die sin van hulle lewe in Hom vind.

\subsubsection{God se Woord in mensewoorde}

Wat maak die Bybel anders as alle ander boeke? Hierop kan geantwoord word: die Bybel is God se geinspireerde Woord. Dié antwoord is egter al so ingeburger. En tog bedoel alle gebruikers van die uitdrukking nie dieselfde daarmee nie. Vervolgens word daar aan die verskillende gebruiksmoontlikhede van die uitdrukking aandag gegee.

Van Huyssteen gebruik die term inspirasie in 'n omvattende betekenis. Volgens hom verwys inspirasie na die kwaliteit van die Bybelse teks. ${ }^{24}$ Die kwaliteit is nie slegs die resultaat van die skryf van die teks nie, maar ook van die lees van die teks. Die skryf en die lees van die teks is vir die realiteit en die interpretasie van die Bybelse teks ewe belangrik. ${ }^{25}$ As die Gees, gaan Van Huyssteen voort, die kreatiewe en die lewegewende teenwoordigheid van God is, dan kan inspirasie nie slegs aan die finale produk van die teks toegeskryf word nie. ${ }^{26}$ Maar dieselfde Gees wat werksaam is in die gemeenskap wat die teks skep, is ook teenwoordig in die gemeenskap wat die teks herskep deur dit te lees en te interpreteer vir vandag. ${ }^{27}$

Voordat Van Huyssteen se aanwending van die begrip inspirasie oorweeg word, moet 'n eie posisie oor die woord eers opgeklaar word. Onder inspirasie kan die woorde wat onder aandrang van die Gees ontstaan het, verstaan word. Die woorde wat op hierdie wyse ontstaan het. is van die Gees deurdrenk. ${ }^{28}$ Die woorde skenk lewe (vgl. Rom 1:16). Daar kan met Van Huyssteen saamgestem word as hy van die kwaliteit van die Bybelse teks praat. ${ }^{29}$ Die onderskeid tussen die teksgebeure en die leesgebeure mag egter nie uit die oog verloor word nie. Die term inspirasie verwys slegs na die teksgebeure, terwyl die lees- en interpretasiegebeure met die begrip verligting verduidelik moet word. Die onderskeid tussen inspirasie-en verligting kan soos voig toegelig word: inspirasie het te doen met die ontstaan, terwyl verligting oor die verstaan van die teks gaan. In die lig van dié verstaan van die term inspirasie is Van Huyssteen se siening van die begrip 'n oorspanning van die woord.

Oor die vraag na die wyse waarop die inspirasie deur die Gees plaasvind, kan ons sê dat die Gees se Woordskeppende handelinge nie die herinterpretasie van tekste uitsluit nie. In die verband kan daar op die volgende voorbeeld gewys word. Die Bybelskrywers wend tekste net soos ander skrywers vir hulle doel daarmee aan. Die wyse waarop die Bybelskrywer met tekste omgaan kom in die verskil in bewoording tus- 
sen 1 Konings 8:25 en 2 Kronieke 6:16 helder aan die lig. In die Koningsteks staan daar dat die koning "voor die aangesig van God" moet lewe. In die Kronieketeks staan daar egter dat die koning "volgens die Wet van God" moet lewe. Ons het hier 'n voorbeeld van 'n "redigering" aan 'n bestaande teks (want die twee tekste vertel oor dieselfde gebeure), en waar ' $n$ klein wysiging vir ons ' $n$ aanduiding gee dat die meer vae "wandel volgens die wil van die Here" later omskryf is met "lewe volgens die maatstaf wat God gegee het, naamlik sy Wet". ${ }^{30}$

God se Woord in mensewoorde het gesag. Die vraag waaroor daar duidelikheid verkry moet word, is: wat is die aard van die gesag? Bavinck het reeds 'n onderskeid gemaak tussen auctoritas historica en auctoritas normativa. God se openbaring vloei in die bedding van die geskiedenis. $\mathrm{Nie}$ alles wat in die Bybel opgeteken is, het normatiewe gesag vir ons geloof en lewe nie. Baie van wat deur God gebied en ingestel of deur die profete en apostels voorgeskryf is, gaan ons nie meer regstreeks aan nie. Die bevel aan Abraham om sy seun te offer, die bevel aan Israel om al die Kanaäniete dood te maak, die seremoniële en burgerlike wette geld nie meer vir ons nie. ${ }^{31}$

Die gesag van die Bybel is 'n heilsgesag. Die gesag van die Bybel lê ten diepste op religieuse vlak ${ }^{32}$ deurdat die Bybel primêr die ontmoeting met God drie-enig bemiddel. ${ }^{33}$ Die Ou en Nuwe Testament het goeie nuus vir die mens: God gee sy heil verniet aan mense. Die heilsbewerking (teokrasie en Christologie), die heilseffektuering (pneumatologie), die heilsbelewing (ekklesiologie en kosmologie) en die heilsvoltooiing (eskatologie) is die hart van die Bybelse verkondiging. Die Bybel is wesenlik 'n geloofsboek met 'n radikale religieuse dimensie. ${ }^{34}$ Dié dimensie kom ook daarin na vore dat dit nie "geslote" tekste nie, maar "oop" tekste bevat. Die onderskeid tussen "geslote" en "oop" tekste kom van Umberto Eco. ${ }^{35}$ Die "geslote" teks is vir hom dit (soos Superman) wat pasklaar aan die leser uitgelewer word vir verbruik: daar is geen "oop plekke" (Iser se term) in nie, niks by te voeg of te dink nie. In dié opsig is die Bybel ook nie 'n "geslote" teks nie. 'n "Oop" teks is vir Eco 'n teks waarin ' $n$ modelleser as't ware in die teks ingebou is: dit word met vertroue aan hom oorgelaat om die "oop plekke" in te vul - maar omdat die modelleser self in die teks geteken word, is die aard van sy invulling eintlik beperk en voorspelbaar. Die Bybel is in dié sin 'n "oop teks" dat die leser die "oop plekke" deur sy beaming van die heil moet invul. Die aard van sy invulling is voorspelbaar. As hy bevestigend op die heilswoorde antwoord, is hy ' $n$ burger van God se koninkryk, 'n bondgenoot van God. Verder is die aard van die mens se invulling beperk. Hy word tot die aanvaarding van die heil oorreed. Die oorreding wat op die aanvaarding van die heil uitloop, is die Heilige Gees se werk. Die Heilige 
Gees maak van God se gesagvolle Woord gebruik om die mens tot die heil te oorreed. Hy beweeg die mens daartoe om hom aan die gesagvolle en betroubare Woord oor te gee. En as dit gebeur is God se Woord elke dag die lig op die mens se pad.

2. Die Skrif is in die kerk oorgelewer as gesaghebbende boodskap van Godsweë. Daarom moet dit weer en weer bestudeer, uitgelê en gepreek word

\subsection{Die gesag van die prediking}

Die gesag van die prediking lê daarin dat dit die prediking van God se Woord is. Die prediking het gesag omdat God se Woord deur die prediking aan die woord kom. Dié gesag bestaan nie in sy effek nie, maar in sy gebondenheid aan die Woord van God. Die prediking is as't ware soos 'n parasiet: dit kan net leef en invloed uitoefen omdat dit uit die Woord leef en daarvan afhanklik is.

\subsection{Verbi Dei minister}

\subsubsection{Die prediker as dienaar}

'n Prediker kan eers vir ander preek as die Woord vooraf deur sy eie hart gegaan het. ' $n$ Prediker mag alleen iemand anders oproep om die gepredikte Woord te glo as hy dit self glo. En of hy die Woord glo, word deur sy lewe ontken of bevestig. Dienaar van die Woord beteken daarom om in die Woord se greep te leef. Wie in die Woord se greep verkeer, kan deur die Woord 'n greep op ander uitoefen. Eintlik is dit nie die dienaar wat ' $n$ greep op ander uitoefen nie, maar die Heilige Gees wat deur hom werksaam is.

'n Dienaar staan ook nie in sy eie diens nie, maar in sy eienaar se diens. Die dienaar van die Woord staan daarom in sy Eienaar, God se diens. Wanneer die prediker God se Woord bedien, is hy daarom met Godsdiens besig. Hy kan ook nie anders nie, want hy is maar net ' $n$ bode met 'n boodskap: "So sê die Here."

\subsection{Verstaanbaarheid}

Prediking is die verkondiging van God se Woord aan mense. Daar word nie vir engele gepreek nie, maar vir mense. Daarom moet daar so gepreek word dat mense die Woord kan verstaan. Die prediker het die onontwykbare taak om die prediking verstaanbaar te maak. Daar is geen 
verskoning vir onverstaanbare prediking nie. Die prediker moet daarom noulettend aandag gee aan die vereistes vir verstaanbare prediking. Daar kan net so terloops op die volgende aspekte gelet word:

2.3.1 Die prediker moet die teks self eers goed verstaan. Dit beteken dat hy nie 'n teks wat nog nie ryp is nie mag pluk nie. ' $n$ Teks is ryp om gepluk te word as die prediker duidelikheid het oor die historiese (die oorspronklike, korrekte en volledige teks; die geskiedenis van die teks: ontstaan, groei, bedoeling) die grammatiese (wat beteken die woorde, uitdrukkings, sinne?) en die literêre vrae (genre?; konteks?; struktuur?; effek?; literêre teorieë?).

2.3.2 Die prediker moet steeds in gedagte hou dat die taal in diens van die boodskap staan. Die prediker moet daarteen waak dat die taal gebruik word om die boodskap soos Josef se rok te versier. As dit gebeur, trek die rok al die aandag en die boodskap gaan ongesiens verby. Die prediker moet die taal in al sy seggingskrag ontgin. Dit beteken dat hy eenvoudig en helder moet preek.

2.3.3 Wanneer die prediker die situasie waarbinne die prediking plaasvind in ag neem, kan die preek nie in die lug bly hang nie, maar is dit konkreet en kontekstueel.

2.3.4 Die prediker moet sensitief wees vir die vereistes van goeie kommunikasie. Anders gesê: hy moet bewus wees van watter negatiewe sake egte kommunikasie in die wiele kan ry. Daar is talle kommunikasiehindernisse, maar egtheid bly in die prediking altyd 'n onvervangbare deug.

\subsection{Die krag van die Woord}

Die krag van die Woord het natuurlik alles met sy gesag te doen. Omdat dit God se Woord is, het dit krag. Luther het hom soos volg oor die saak uitgedruk: "Al wat ek gedoen het is om die Woord na vore te bring, te preek en te skryf, en afgesien hiervan het ek niks gedoen nie. Terwyl ek geslaap het, of Wittenberg bier saam met my vriend Philip en saam met Amsdorf gedrink het, is dit die Woord wat wondere verrig het ... ek het niks gedoen nie; die Woord het alles gedoen en vermag. As ek met mag sou optree, sou dit ' $n$ groot bloedbad in Duitsland veroorsaak het, en ek sou so 'n konsternasie by Worms laat ontstaan het dat die Keiser nie gered sou word nie. Maar wat sou dit alles tot gevolg hê? Dit sou 'n spel van dwase wees. Ek het niks gedoen nie, ek het die Woord sy gang laat 
gaan ... dit is magtig, dit neem die harte gevange, en wanneer dit gebeur, is die werke wat tot stand kom deur die Woord verrig."36

Die Woord van God is kragtig, want dit is kerugma. Met kerugma word bedoel: dit kondig God se heil vir die mens en die wêreld aan.

Die Woord van God is kragtig, daarom is dit ' $n$ verkondiging met ' $n$ appèl. Die appèl van die Woord is dat mense die evangelie moet glo. Die evangelie is dat God goddelose mense vryspreek omdat Christus hulle skuld gedra het. En wanneer mense die vryspraak aanvaar het, moet hulle daaruit leef. Die aanvaarding van die goeie nuus is egter nie eintlik mensewerk nie, maar die werk van die Gees. Hy gebruik die verkondigde Woord om mense tot geloof te oorreed. Daar kan met Erich Auerbach saamgestem word as hy sê dat die vertellings van die Skrif nie daarop gerig is om soos die van Homeros ons guns te wen nie, dit wil ons ook nie vlei om ons te behaag en te betower nie - dit wil ons onderwerp, en as ons weier om onderwerp te word, is ons rebelle.

\subsection{Aktualiteit}

Die aktualiteit van die Woord lê nie in die situasie nie, maar in die feit dat dit God se spreke vir mense van alle tye is. Die spreke is aktueel, omdat die boodskap van die Woord aktueel is. En die boodskap is heil vir mense en die wêreld.

\subsection{Prediking is evangelie}

Wanneer het ' $n$ preek geslaag? As dit iemand bly maak. Die evangelie is bedoel om mense bly te maak. Elke keer as ' $n$ mens hoor dat God sy guns verniet aan mense toegesê het, is daar rede tot oorstelpende blydskap.

Slotsom: Daar moet in die kerk en in die teologie ' $n$ hoë prys op die belydenis dat die Woord van God gesag het, geplaas word. Daar moet ook duidelikheid oor dié belydenis bestaan. Slegs as dit die geval is, kan die prediking as gesagvolle spreke helder weerklink en gehoor word.

\section{NOTAS}

1. J A Heyns, Dogmatiek, Pretoria 1978, 376.

2. Wentzel van Huyssteen, Teologie as kritiese ge/oofsverantwoording, Pretoria 1986, 138.

3. Wentzel van Huyssteen, The realism of the text. A perspective on biblical authority, Pretoria 1987, 34.

4. Vgl. in die verband S Ogden, "The authority of scripture for theology", Inspiration 
30 (1976), $242-261$ en Van Huyssteen, a.w., 1987, 34.

5. Van Huyssteen, a.w., 1986, 193.

6. Van Huyssteen, a.w., 1987, 46-47.

7. Vgl. G C Berkouwer, De Heilige Schrift 1, Kampen 1966, 83-138.

8. F E Deist, Kan ons die Bybe/ dan nog glo?, Pretoria 1986, 124

9. Van Huyssteen, a.w., 1987, 19.

10. Idem

11. H W Rossouw, Wetenskap, interpretasie, wysheid, Port Elizabeth 1981, 20.

12. J W V van Huyssteen en B J du Toit, Geloof en Skrifgesag, Pretoria 1982, 36.

13. Idem. Vgl. ook J Barr, Escaping from fundamentalism, London 1984.

14. A C Hofland, $\mathrm{H} J$ Kouwenhoven, $\mathrm{C} \mathrm{H}$ van den Berg, E Elkerbout, God met ons ... over de aard van het Schriftgezag, 1980. Vgl. ook H J Bavinck, C van Gelder, C J den Heyer, J C de Moor, Opdat gij gelooft ... oefeningen in bijbellezen, s.a.

15. Hofland, Kouwenhoven, Van den Berg, Edelbout, a.w., 5-8.

16. Ibid., 9.

17. Ibid., $10-11$.

18. Ibid., $11-14$.

19. Ibid., 15.

20. Idem.

21. Deist, Sê God so?, Kaapstad 1982, 23.

22. Deist, a.w., 1982, 47.

23. Ibid., 48. Vgl. ook pp. 51-52.

24. Van Huyssteen, a.w., 1987, 48.

25. Ibid. , $48-49$.

26. Ibid., 49.

27. Ibid., 50.

28. Deist, a.w., 1986, 70.

29. Van Huyssteen, a.w., 1987, 48.

30. Deist, a.w., 1986, 91.

31. H Bavinck, Gereformeerde Dogmatiek. Eerste Deel, Kampen 1967, 427-428.

32. Van Huyssteen, a.w., 1986, 210.

33. Idem.

34. Ibid., 193.

35. Vgl. U Eco, The roll of the reader, Bloomington 1979.

36. G Ebeling, Luther. Einführung in sein Denken, Tübingen 1978, 67-68. 